\title{
Author Correction: Guidelines and definitions for research on epithelial-mesenchymal transition
}

Jing Yang (D), Parker Antin, Geert Berx, Cédric Blanpain, Thomas Brabletz, Marianne Bronner, Kyra Campbell, Amparo Cano, Jordi Casanova, Gerhard Christofori, Shoukat Dedhar, Rik Derynck, Heide L. Ford, Jonas Fuxe (D, Antonio García de Herreros, Gregory J. Goodall, Anna-Katerina Hadjantonakis, Ruby Y. J. Huang, Chaya Kalcheim, Raghu Kalluri, Yibin Kang D, Yeesim Khew-Goodall, Herbert Levine, Jinsong Liu, Gregory D. Longmore, Sendurai A. Mani, Joan Massagué, Roberto Mayor (iD, David McClay, Keith E. Mostov (D), Donald F. Newgreen (D), M. Angela Nieto (D), Alain Puisieux (D), Raymond Runyan (D),

Pierre Savagner, Ben Stanger, Marc P. Stemmler (D), Yoshiko Takahashi, Masatoshi Takeichi (D), Eric Theveneau (D), Jean Paul Thiery (D), Erik W. Thompson (D), Robert A. Weinberg, Elizabeth D. Williams (D), Jianhua Xing (D), Binhua P. Zhou, Guojun Sheng and On behalf of the EMT International Association (TEMTIA)

Correction to: Nature Reviews Molecular Cell Biology https://doi.org/10.1038/s41580-020-0237-9, published online 16 April 2020.

In the supplementary information, the reference to Contreras et al. 2016 was removed (as it relates to a gene different from E2-2/TCF4), and '(TCF7L2)' was deleted from the table. Misspellings in the author name Ruby Y. J. Huang and in the PyMT glossary definition were also corrected. These changes have been made to the HTML and PDF versions of the article.

https://doi.org/10.1038/s41580-021-00428-9 I Published online 15 October 2021

Open Access This article is licensed under a Creative Commons Attribution 4.0 International License, which permits use, sharing, adaptation, distribution and reproduction
in any medium or format, as long as you give appropriate credit to the original author(s) and the source, provide a link to the Creative Commons licence, and indicate if changes
were made. The images or other third party material in this article are included in the article's Creative Commons licence, unless indicated otherwise in a credit line to the
material. If material is not included in the article's Creative Commons licence and your intended use is not permitted by statutory regulation or exceeds the permitted use, you will need to
obtain permission directly from the copyright holder. To view a copy of this licence, visit http://creativecommons. org/licenses/by/4.0/.

(C) The Author(s) 2021 